\title{
Estrogen inhibits D2S receptor-regulated Gi3 and Gs protein interactions to stimulate prolactin production and cell proliferation in lactotropic cells
}

\author{
A Sengupta and D K Sarkar \\ Endocrinology Program and Department of Animal Sciences, Rutgers, The State University of New Jersey, 67 Poultry Farm Road, New Brunswick, \\ New Jersey 08901, USA \\ (Correspondence should be addressed to D K Sarkar; Email: sarkar@aesop.rutgers.edu)
}

\begin{abstract}
The neurotransmitter dopamine (DA) is known to inhibit prolactin (PRL) secretion and the proliferation of lactotropes in the pituitary gland. Dopamine-2 (D2) receptor short (D2S) isoform is expressed in a reduced level while the $\mathrm{D} 2$ receptor long (D2L) isoform is expressed in an elevated level during estradiol $\left(\mathrm{E}_{2}\right)$-induced PRL production and cell proliferation in lactotropes. To evaluate the role of these D2 receptor isoforms in $E_{2}$-regulated lactotropic cell function, we compared $\mathrm{E}_{2}$ effects on the level of PRL, cell proliferation, and $G$ proteins in enriched lactotropes and lactotrope-derived PR1 cells containing only D2S isoform (D2S cells), D2L isoform (D2L cells), or no D2 receptor (V cells). Additionally, we determined the effects of $G$ protein blockade on the $E_{2^{-}}$ induced PRL production and cell proliferation in these cells.
\end{abstract}

We here show that $\mathrm{E}_{2}$ actions on $\mathrm{G}$ proteins, $\mathrm{PRL}$ production, and cell proliferation were maximally achieved in D2S cells, oppositely or marginally achieved in D2L cells, and absent in $\mathrm{V}$ cells. We also show that the DA and pertussis toxin modulations of $\mathrm{E}_{2}$ actions on PRL, G proteins, and cell proliferation were maximally achieved in D2S cells compared with in D2L or V cells. Furthermore, we provide evidence for the existence of an inhibitory action of Gi3 on Gs that is under the control of the D2S receptor and is inhibited by $\mathrm{E}_{2}$. These results suggest that the suppression of D2S-regulated Gi3 inhibition of Gs protein may be one of the mechanisms controlling $\mathrm{E}_{2}$-activated PRL synthesis and cell proliferation in lactotropes.

Journal of Endocrinology (2012) 214, 67-78

\section{Introduction}

In the pituitary, the secretion and proliferation of prolactin (PRL)-secreting lactotropes are controlled by hypothalamic hormones that act via $G$ protein-coupled receptors, sharing the common structural and functional motif characterized by seven transmembrane domains (Baldwin 1994, Gershengorn \& Osman 1996). Dopamine (DA) is one of the hormones that play a key role in maintaining the normal function of lactotropes in the pituitary gland (Freeman et al. 2000, Ben-Jonathan \& Hnasko 2001). DA binds to dopamine-2 (D2) receptors that are coupled to pertussis toxin (PTX)-sensitive Gi/Go proteins (Civelli et al. 1993, Albert 2002). The activation of $\mathrm{Gi}$ and $\mathrm{Go}$ heteromeric proteins causes activation of an inwardly rectifying potassium channel that leads to the inactivation of voltage-gated calcium channels, reduction in intracellular free calcium, and inhibition of PRL release (Vallar \& Meldolesi 1989, Sarkar 2006). In addition to its effect on PRL release, DA also inhibits PRL production and cell proliferation of lactotropes (Ben-Jonathan \& Hnasko 2001). Abnormalities in DA secretion, D2 receptors, and DA transporter functions lead to hyperplasia of lactotropes and the development of PRL-secreting prolactinomas (Sarkar et al. 1982, Bosse et al. 1997, Kelly et al. 1997, Saiardi et al. 1997). How DA controls PRL production and cell proliferation of lactotropes is not well understood.

D2 receptors exist into two distinct isoforms: long form (D2L) and short form (D2S), which are generated by alternative splicing. The D2L subtype differs from the D2S subtype by an insertion of 29 amino acids in the third intracytoplasmatic protein loop. This polypeptide region is involved in G protein coupling of the D2 receptor, and therefore, the two D2 receptor subtypes may be associated with different $G$ proteins or may induce different effects when coupled to the same G protein (Civelli et al. 1993, Guiramand et al. 1995). As described by an extended allosteric ternary complex model of $\mathrm{G}$ protein-coupled receptor activation, receptors spontaneously isomerize between active and inactive conformations, so receptors can modulate signaling pathways in the absence of an agonist. In addition, significant constitutive activity of recombinant D2S receptors expressed in mammalian cells has been described previously (Wiens et al. 1998). In vitro studies suggest that the two isoforms might activate different signaling pathways in vivo (Guiramand 
et al. 1995). In lactotropes, there is greater expression of D2L over D2S receptors in the presence of estradiol $\left(\mathrm{E}_{2}\right.$; Guivarc'h et al. 1998, Oomizu et al. 2003). Analyses with genetically modified mice have recently supported the hypothesis that D2L and D2S might have different functions in vivo (Usiello et al. 2000, Wang et al. 2000). However, how the differential activation of $\mathrm{G}$ proteins by two D2 isoforms might govern $\mathrm{E}_{2}$-activated $\mathrm{PRL}$ production and cell proliferation in the lactotrope is not known. To evaluate the role of these D2 receptor isoforms in $\mathrm{E}_{2}$-regulated lactotropic cell function, we compared $E_{2}$ 's effects on the level of $G$ proteins (Gi3, Gs, and Gq11), PRL, and cell proliferation in enriched lactotropes (E-LT), lactotrope-derived PR1 cells with undetected levels of $\mathrm{D} 2$ receptors (V cells), or containing D2S receptor isoform (D2S cells) or D2L receptor isoform (D2L cells). Additionally, we determined the effect of Gi3, Gs blockade on $E_{2}$ 's ability to induce PRL levels in V, D2S, and D2L cells.

\section{Materials and Methods}

\section{Primary cultures of E-LT}

In limited experiments, E-LT were used. Anterior pituitaries from female Fisher 344 rats were used to prepare E-LT (about 75-80\% lactotropes) using the percol gradient method (Burris \& Freeman 1993) and maintained in primary cultures as we described previously (Hentges et al. 2000). Animal surgery and care were performed in accordance with institutional guidelines and complied with the National Institutes of Health policy. The animal protocol used was approved by the Rutgers Animal Care and Facilities Committee. Cells were maintained at $37{ }^{\circ} \mathrm{C}$ in $7 \cdot 5 \% \mathrm{CO}_{2}$ for $72 \mathrm{~h}$ in phenol red-free DMEM (Sigma) containing 10\% fetal bovine serum (FBS) and then for $24 \mathrm{~h}$ in serum-free DMEM containing serum supplement (SS) consisting of human transferrin $(100 \mu \mathrm{M})$, insulin $(5 \mu \mathrm{M})$, putrescine $(1 \mu \mathrm{M})$, and sodium selenite $(30 \mathrm{nM})$ before treatment with the tested agent. We used $0 \cdot 25$ million cells/well in a 12 -well plate for PRL production (gene transcription and cellular protein content) experiments and 0.5 million cells/well in a six-well plate for cell proliferation studies. Cultures were treated with various doses of $E_{2}$ (water soluble; Sigma) for a period of $24 \mathrm{~h}$.

\section{PR1 cells expressing various amount of $D A D 2$ receptors}

We used a well-characterized PRL-secreting PR1 cell line (Pastorcic et al. 1995, Chun et al. 1998, Caporali et al. 2003). Previously, using these cells, we have made several stable transfectants expressing undetectable amount of DA D2 receptors (V cells), containing the recombinant $\mathrm{D} 2 \mathrm{~L}$ receptor (D2L cell) or D2S receptors (D2S cell) (Sarkar et al. 2005, Radl et al. 2011). Before use in this study, we verified the expression patterns of D2 receptors in these cell lines. Transfectants of PR 1 cells were maintained in a 1:1 mixture of
DMEM and Ham's F-12 medium (DMEM-F-12; Sigma) containing $10 \%$ FBS and $800 \mu \mathrm{g} / \mathrm{ml} \mathrm{G}-418$ sulfate (Promega). We used $0 \cdot 25$ million cells/well for PRL production experiments and 0.5 million cells/well for cell proliferation studies. Before the treatment with a tested agent, cells were maintained for $24 \mathrm{~h}$ in serum-free DMEM/F-12 with SS. Cells were treated with various doses of $E_{2}$ for a period of $24 \mathrm{~h}$ in order to determine the dose-response effect of the steroid on PRL and G protein levels and cell proliferation. For determination of the role of DA receptors and $G$ proteins in $\mathrm{E}_{2}$-activated PRL production and cell proliferation, cells were treated with $10 \mathrm{nM}$ of $\mathrm{E}_{2}$ in the presence or absence of DA $(5 \mu \mathrm{M})$ and PTX $(10 \mu \mathrm{g} / \mathrm{ml})$ alone or together for a period of $24 \mathrm{~h}$. We used a $24 \mathrm{~h}$ treatment time in order to produce a significant effect on PRL production and cell proliferation. Cells were lysed and levels of proteins were detected by western blot or used for $P R L$ gene transcription assay. Cell proliferation was determined by $\left[{ }^{3} \mathrm{H}\right]$-thymidine incorporation assay.
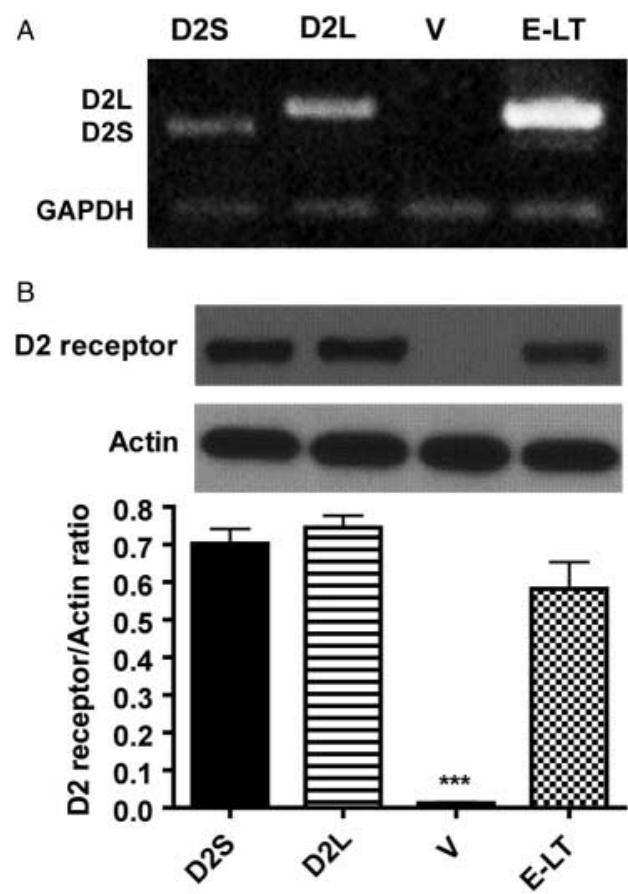

Figure 1 Comparison of the expression pattern of D2L, D2S, and $\mathrm{D} 2$ receptor $\mathrm{mRNA}(\mathrm{A})$ and protein (B) levels in E-LT, D2S, D2L, and $\checkmark$ cells. (A) Representative gel figure showing expression of $\mathrm{D} 2 \mathrm{~L}$ and D2S mRNA in D2S, D2L, V, and E-LT cells as detected by RT-PCR. For the loading controls, the levels of GAPDH mRNA were measured in the same cell samples and are shown in the bottom gel figure. The transcripts for D2L, D2S, and GAPDH are indicated on the left. (B) The level of D2 receptor protein in all cells was measured using $25 \mu \mathrm{g}$ of cellular proteins of each cell in western blots. Actin was used as control housekeeping protein. In each column of the figure, representative blots are shown on the top, and mean \pm S.E.M. values of $\mathrm{D} 2$ receptor protein and actin ratios are presented as histograms on the bottom. $n=4{ }^{* * *} P<0 \cdot 001$, significantly different from the rest of the groups. 
Detection of D2S and D2L $m R N A$ expression

The gene expression patterns of $\mathrm{D} 2$ receptor $\mathrm{mRNA}$ were measured using the RT-PCR method. cDNA was prepared using random hexamer primers and the Superscript reverse transcriptase kit (Invitrogen) using the methods described by the manufacturers. The sequence of the $5^{\prime}$ forward primer of D2 receptor was TTCGAGCCAACCTGAAGACACCA, and the sequence of the $3^{\prime}$ reverse primer was GCTTTCTGCCGCTCATCGTCTTAA. Measurement of glyceraldehyde-3-phosphate dehydrogenase (GAPDH) mRNA expression as an internal standard for calibration was performed using a control reagent (PerkinElmer Applied Biosystems, Foster City, CA, USA). The amplification conditions for PCR were described by us previously (Oomizu et al. 2003).

\section{Western blot}

Cellular levels of $\mathrm{G}$ proteins and PRL were determined by western blots using the ECL western blot chemiluminescence reagent as we described previously (Chaturvedi \& Sarkar 2008). All the primary and secondary antibodies used in this study were previously characterized (Chaturvedi \& Sarkar 2008). The primary antibodies used were rabbit anti-rPRL $(1: 30000)$, D2 receptor antibody $(1: 1000)$, Gs antibody (1:1000), rabbit anti-Gq11 antibody (1:1000), rabbit anti-Gi3 antibody (1:1000), and mouse anti-actin antibody (1:5000). All antibodies were purchased from Santa Cruz Biotechnology, except for anti-rat PRL, which was obtained from the National Institute of Diabetes and Digestive and Kidney Diseases (NIDDK; PRL-S9) and anti-Gi3 and actin antibodies, which were purchased from Upstate Biotechnology (Cleveland, OH, USA) and EMD Chemical (Gibbstown, NJ, USA) respectively. For quantification of protein levels, the same amount of total cellular protein for all the samples was used in the assay. The band intensities of proteins were determined using Scion Image Software (Scion Corporation, Frederick, MD, USA) and normalized to the corresponding actin band intensities. The $\mathrm{E}_{2}$ treatment protocol used did not affect the level of cellular actin. Hence, G proteins and PRL levels were normalized with actin levels, and the ratios of $\mathrm{G}$ protein/actin and PRL/actin were determined and presented in the text and figures.

\section{PRL gene transcription}

$P R L$ gene transcription was measured using luciferase reporter activity and luciferase reporter construct containing $\sim 2.5 \mathrm{kbps}$ of the $5^{\prime}$-flanking sequence and the promoter from the rat $\mathrm{Prl}$ gene (Maurer 1989) provided by Dr Arthur Gutierrez-Hartmann from UCHSC. Briefly, the cells were transfected by a superfect reagent (Qiagen) with a plasmid containing the luciferase structural gene fused to $2.5 \mathrm{~kb}$ of the $5^{\prime}$-flanking region of the rat $\mathrm{Prl}$ gene following the manufacturer's protocols. After transfection, cells were incubated with the serum-free media containing SS for $24 \mathrm{~h}$ before treatment with various doses of $\mathrm{E}_{2}$ or vehicle control for $24 \mathrm{~h}$. The luciferase activity for each culture plate was determined using the Dual-Glo luciferase assay system (Promega).

\section{Cell proliferation response}

Cell proliferation was determined by the $\left[{ }^{3} \mathrm{H}\right]$-thymidine incorporation methods as described by us previously (Sarkar et al. 2005). Each experiment was conducted in duplicate and repeated three times. In some experiments, because samples were run in multiple assays, the d.p.m. values of each treatment varied between assays, and therefore, data were calculated and presented as percentage of control.

\section{Knockdown of Gi3 and Gs proteins with siRNA}

Rat siRNAs for Gi3 (Rn_Gnai3_5_HP siRNA; gene accession number NM_013106) and Gs (Rn_Gnas_HP siRNA; gene accession number NM_001024823) were bought from Qiagen as lyophilized powder. Each of them was $74 \mu \mathrm{g} /$ tube $(5 \mathrm{nmol} /$ tube). D2L and D2S cells were transfected with $37 \cdot 5 \mathrm{ng} / 1.5 \mu \mathrm{l}$ of each siRNA and $3 \mu \mathrm{l} / \mathrm{ml}$ HiPerfect Reagent (Qiagen) in a final volume of $100 \mu \mathrm{l}$ serum-free culture medium with SS and incubated for $10 \mathrm{~min}$ at room temperature for complex formation. The transfection mix was then added onto cells with or without

Table 1 Comparison of the basal level of PRL gene transcription, cell content of PRL and cell proliferation in E-LT, V cells, D2S cells or D2L cells

\begin{tabular}{|c|c|c|c|}
\hline Coll tynes & $\begin{array}{c}\boldsymbol{P R L} \text { gene transcription } \\
\text { (Renilla:firefly) }\end{array}$ & PRL content (PRL:actin) & $\begin{array}{c}{\left[{ }^{3} \mathrm{H}\right] \text {-thymidine incorporation }\left(1 \times 10^{3}\right.} \\
\left.\text { d.p.m. } / 1 \times 10^{4} \text { cells }\right)\end{array}$ \\
\hline E-LT & $1 \cdot 36 \pm 0 \cdot 4(n=4)$ & $0 \cdot 23 \pm 0 \cdot 01(n=3)$ & $10 \cdot 4 \pm 0 \cdot 4(n=8)$ \\
\hline D2S & $1 \cdot 26 \pm 0 \cdot 09(n=4)$ & $0 \cdot 16 \pm 0 \cdot 01^{\mathrm{a}}(n=3)$ & $10 \cdot 9 \pm 0 \cdot 4(n=8)$ \\
\hline $\mathrm{D} 2 \mathrm{~L}$ & $1 \cdot 1 \pm 0 \cdot 5(n=4)$ & $0 \cdot 27 \pm 0 \cdot 01(n=3)$ & $11 \cdot 3 \pm 0 \cdot 2(n=8)$ \\
\hline V & $3 \cdot 05 \pm 0 \cdot 6^{b}(n=4)$ & $0 \cdot 78 \pm 0 \cdot 02^{\mathrm{b}}(n=3)$ & $12 \cdot 2 \pm 0 \cdot 4^{\mathrm{c}}(n=9)$ \\
\hline
\end{tabular}

\footnotetext{
${ }^{\mathrm{a}} P<0 \cdot 001, \mathrm{D} 2 \mathrm{~S}$ vs E-LT and D2L.

${ }^{\mathrm{b}} P<0 \cdot 001, \vee$ vs E-LT, D2L, and D2S.

${ }^{\mathrm{c}} P<0 \cdot 05, \mathrm{~V}$ vs E-LT and D2S.
} 
$10 \mathrm{nM} \mathrm{E}_{2}$ and incubated at $37^{\circ} \mathrm{C}$ and $7 \cdot 5 \% \mathrm{CO}_{2}$ for $24 \mathrm{~h}$ and used for protein measurement by western blot.

\section{Measurement of PRL levels}

PRL levels in cellular extracts of some samples were verified by ELISA assay (Alpco Immunoassays, Salem, NH, USA). Cellular extract $(10 \mu \mathrm{g} / \mathrm{ml})$ of the culture was added to the microplate coated with a monoclonal anti-rat PRL antibody. A standard curve between 5 and $80 \mathrm{ng} / \mathrm{ml}$ PRL was used to compare the content of PRL in the experimental samples.

\section{Statistical analysis}

The data shown in the figures and text are mean \pm s.E.M. of values obtained from three separate identical experiments. Data were compared between multiple treatment groups using a one-way ANOVA. Student-Newmann-Keuls test was used as a post hoc test. GraphPad Prism 4.0 (GraphPad Software, Inc., San Diego, CA, USA) was used for statistical analyses and graph preparation. A value of $P<0.05$ was considered significant.

\section{Results}

Effects of differential expression of D2 receptors on $P R L$ production and cell proliferation in lactotropes

We first evaluated whether constitutive expression of an individual D2 receptor isoform affects lactotropic cell functions. We used E-LT cells containing intact D2 receptors, $\mathrm{V}$ cells containing no D2 receptors, D2L cells containing only D2L isoform, and D2S cells containing only D2 receptor short isoform (Sarkar et al. 2005; Fig. 1A). Measurement of D2 receptor protein levels indicated that E-LT cells, D2L cells, and D2S cells contain similar levels of this receptor protein while $\mathrm{V}$ cells had no detectable amount of this receptor protein (Fig. 1B). Determination of $P R L$ gene transcription in four cell types revealed that the transcription rate was higher under basal condition in V cells than in E-LT, D2L, or D2S cells (Table 1). Cell contents of PRL were also different in these four cell types; the highest amount of PRL was found in $\mathrm{V}$ cells and the lowest amount was detected in D2S cells. Basal cell growth rate, as determined by $\left[{ }^{3} \mathrm{H}\right]$-thymidine incorporation rate, was also different in these cell lines. The thymidine incorporation rate was highest in V cells, followed by D2L cells, and then D2S and E-LT cells. These data are in agreement with the established inhibitory role of D2 receptors on PRL synthesis and lactotropic cell proliferation (Ben-Jonathan \& Hnasko 2001) and provide support to the view that constitutive expression of D2 receptor isoforms themselves can affect lactotropic cell functions (Sarkar et al. 2005). In addition, these data identify a possible differential effect of two D2 receptor isoforms on PRL synthesis and cell proliferation in lactotropes.
Effect of $E_{2}$ on PRL gene transcription and cell proliferation in lactotropes or lactotropic cells expressing various levels of D2 receptor isoforms

$\mathrm{E}_{2}$ is a well-known regulator of PRL production and cell proliferation in lactotropes. During $\mathrm{E}_{2}$ activation of PRL production and cell proliferation, an increase in $\mathrm{D} 2 \mathrm{~L}$ receptor and a decrease in $\mathrm{D} 2 \mathrm{~S}$ production have been documented in lactotropes (Guivarc'h et al. 1998, Oomizu et al. 2003). In order to better understand the role of D2 receptor splice
A
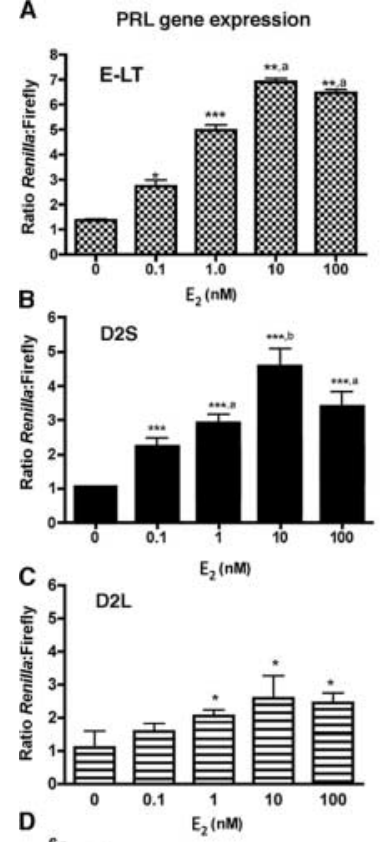

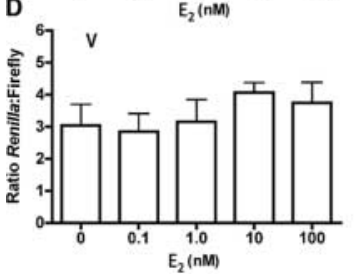

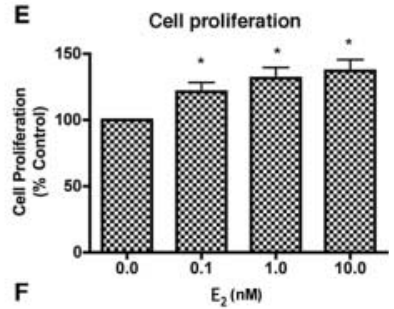

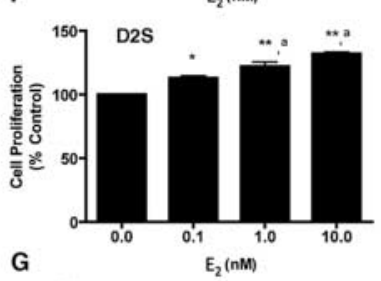

G
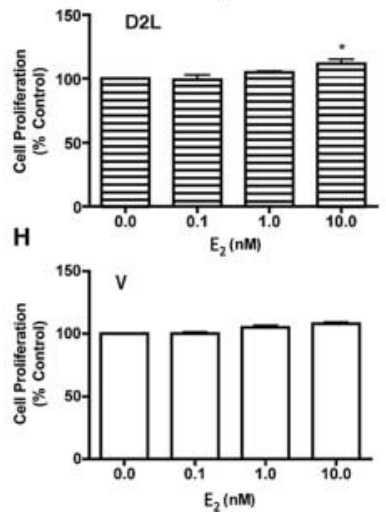

Figure 2 Comparison of the $\mathrm{E}_{2}$-induced $P R L$ gene transcription and cell proliferation responses in E-LT, D2S, D2L, and V cells. (A, B, C and D) Histograms show dose-response effects of $E_{2}$ on $P R L$ gene transcription in E-LT, D2S, D2L, and V cells. PRL gene transcription was measured by luciferase reporter activity and using luciferase reporter construct containing $\sim 2.5 \mathrm{kbps}$ of the $5^{\prime}$-flanking sequence and the promoter from the rat $\mathrm{Prl}$ gene. Cells were treated with various doses of $E_{2}$ for a $24 h$ period. (E, F, G and $H$ ) Histograms comparing the dose-response effects of $E_{2}$ on cell proliferation in $\mathrm{E}-\mathrm{LT}, \mathrm{D} 2 \mathrm{~S}, \mathrm{D} 2 \mathrm{~L}$, and $\mathrm{V}$ cells. Cell proliferation response in D2S, $\mathrm{D} 2 \mathrm{~L}$, and $\mathrm{V}$ cells was determined by measuring the $\left[{ }^{3} \mathrm{H}\right]$-thymidine incorporation into cells. $E_{2}$ treatment time was $24 \mathrm{~h}$. Data are mean \pm S.E.M. values from three to four independent experiments. ${ }^{*} P<0 \cdot 05,{ }^{* *} P<0 \cdot 01,{ }^{* * *} P<0 \cdot 001$ compared with ' 0 ' dose (vehicle)-treated group. ${ }^{\text {a }} P<0 \cdot 05$, significantly different from the ${ }^{\prime} 0 \cdot 1 \mathrm{nM}^{\prime}$ dose-treated group. ${ }^{\mathrm{b}} P<0 \cdot 05$, significantly different from the ' $1 \cdot 0 \mathrm{nM}^{\prime}$ ' dose-treated group. 
Table 2 Comparison of the basal cellular levels of Gi3, Gs, and Gq11 in E-LT, V cells, D2S cells or D2L cells

Cell types
E-LT
D2S
D2L
V

${ }^{\text {a }} P<0 \cdot 001$, E-LT vs D2L.

${ }^{\mathrm{b}} P<0 \cdot 001, \mathrm{D} 2 \mathrm{~S}$ vs E-LT and D2L.

${ }^{\mathrm{C}} P<0 \cdot 001, \mathrm{D} 2 \mathrm{~L}$ vs E-LT and D2S.

${ }^{\mathrm{d}} P<0 \cdot 05, \mathrm{~V}$ vs E-LT and D2S.

e $P<0 \cdot 001, V$ vs E-LT, D2L, and D2S.

\begin{tabular}{lll}
$\frac{\text { Gi3 level (Gi3:actin) }}{0 \cdot 97 \pm 0 \cdot 08(n=7)}$ & & \multicolumn{1}{c}{ Gs level (Gs:actin) } \\
$0 \cdot 82 \pm 0 \cdot 05(n=4)$ & & $0 \cdot 44 \pm 0 \cdot 02^{\mathrm{a}}(n=7)$ \\
$0 \cdot 68 \pm 0 \cdot 01^{\mathrm{c}}(n=4)$ & & $0 \cdot 73 \pm 0 \cdot 03(n=4)$ \\
$0 \cdot 58 \pm 0 \cdot 04^{\mathrm{d}}(n=4)$ & $1 \cdot 05 \pm 0 \cdot 04^{\mathrm{e}}(n=4)$
\end{tabular}

Gq11 level (Gq11:actin)

$1 \cdot 41 \pm 0 \cdot 08(n=7)$

$1 \cdot 79 \pm 0 \cdot 19(n=4)$

$1 \cdot 55 \pm 0 \cdot 15(n=4)$

$2 \cdot 03 \pm 0 \cdot 39(n=4)$ variants in $\mathrm{E}_{2}$ action on lactotropes, we first studied the ligand-independent effect of two D2 isoforms on $\mathrm{E}_{2}$-induced $P R L$ gene transcription and lactotropic cell proliferation. $\mathrm{E}_{2}$ 's dose-response effects on $P R L$ gene transcription were compared between four cell types. $\mathrm{E}_{2}$ increased $P R L$ gene transcription in E-LT and D2S cells in a concentrationdependent manner (Fig. 2A, B, C and D). In both these cell types, a dose of $10 \mathrm{nM} \mathrm{E} E_{2}$ was effective in inducing the maximum effect. $\mathrm{E}_{2}$ also moderately increased $P R L$ gene transcription in D2L cells but failed to significantly increase in $\mathrm{V}$ cells (Fig. 2C and $\mathrm{D}$ ). The effective dose of $\mathrm{E}_{2}$ that produced maximal effect on $P R L$ gene transcription rate was used to compare this steroid effect on PRL cell content. Like the $\mathrm{E}_{2}$ effect on $P R L$ gene transcription, the steroid at a dose of $10 \mathrm{nM}$ was most effective in increasing the cellular level of PRL in E-LT (393.0 $\pm 17 \cdot 3 \%$ of control, $n=3)$ and D2S cells $(273 \cdot 0 \pm 7 \cdot 1 \%$ of control, $n=3)$, moderately effective in D2L cells $(126 \cdot 0 \pm 3 \cdot 7 \%$ of control, $n=3$ ), and ineffective in $\mathrm{V}$ cells $(103 \cdot 8 \pm 3 \cdot 6 ; P<0 \cdot 05$, E-LT vs D2S; $P<0 \cdot 001$, D2S vs D2L and V; $P<0 \cdot 05$, D2L vs V). Similarly, the study determining the $\mathrm{E}_{2}$ cell proliferation response revealed D2 receptor dependency (Fig. 2E vs H) and D2S receptor preference of the steroid actions (Fig. 2F, G and H). Together, these data indicate that $E_{2}$ increases $P R L$ production and cell proliferation in lactotropes and lactotrope-derived cells with functional D2 receptors. Additionally, the data show the preference of D2S receptors over D2L receptors in mediation of $\mathrm{E}_{2}$ action on $\mathrm{PRL}$ production and cell proliferation in lactotropes.
Effect of $E_{2}$ on $G$ protein expressions in lactotropic cells expressing various levels of D2 receptor isoforms

$G$ proteins, particularly Gs, are recognized to mediate the stimulatory signals whereas Gi3 is known to mediate the inhibitory signals controlling lactotrope cell functions (Kineman et al. 1996). We have recently shown that the pituitary levels of specific groups of $\mathrm{G}$ proteins ( $\mathrm{Gi} 3$ and $\mathrm{Gs}$ ) are highly responsive to $\mathrm{E}_{2}$, whereas $\mathrm{Gq} 11$ and other $\mathrm{G}$ proteins (Gi1 and Gi2) are insensitive or very moderately responsive to $E_{2}$ (Chaturvedi \& Sarkar 2008). $E_{2}$ stimulatory effect on Gs and inhibitory effect on Gi3 expression have also been demonstrated in lactotropes (Livingstone et al. 1998). However, the contributions of each D2 receptor isoform in regulation of basal and $\mathrm{E}_{2}$ modulation of $\mathrm{G}$ proteins have not been determined. Hence, we compared the basal and $\mathrm{E}_{2^{-}}$ induced changes in cellular levels of $\mathrm{G}$ proteins (Gs, Gi3, and Gq11) in cells expressing different D2 receptor isoforms.

When basal levels of $G$ proteins in different cell lines were compared, we found (see Table 2) that in V cells lacking D2 receptor, the basal levels of Gs were higher than those in E-LT, D2S, and D2L cells. However, the basal level of Gi3 was lower in $\mathrm{V}$ cells than in D2S and E-LT cells. In D2S-expressing cells, the level of Gi3 was higher than in D2L cells but was not significantly different from that in E-LT cells. The level of Gs in D2S cells was lower than both D2L and E-LT cells. In cells expressing D2L, the level of Gi3 was lower than that of both D2S and E-LT cells. The levels of Gq11 in E-LT, D2S, D2L, and V cells were similar. These data suggest that levels of $G$ proteins, particularly $G$ and $\mathrm{Gi3}$, in

Table $3 \mathrm{E}_{2}$-induced changes in cellular levels of Gi3, Gs, and Gq11 in E-LT cells, V cells, D2S cells or D2L cells

Cell types
E-LT
D2S
D2L
V

a $P<0 \cdot 001$, D2S vs E-LT.

${ }^{\mathrm{b}} P<0 \cdot 05$, D2L vs E-LT and D2S.

${ }^{\mathrm{c}} P<0 \cdot 001, \mathrm{~V}$ vs E-LT, D2S, and D2L.

\begin{tabular}{|c|c|}
\hline Gs level ( $\%$ of ' 0 ' dose) & Gq11 level ( $\%$ of ' 0 ' dose) \\
\hline $140 \cdot 5 \pm 2 \cdot 1$ & $101 \cdot 2 \pm 1 \cdot 7(n=8)$ \\
\hline $275 \cdot 1 \pm 3 \cdot 3^{\mathrm{a}}(n=4)$ & $111 \cdot 1 \pm 6 \cdot 3(n=4)$ \\
\hline $124 \cdot 7 \pm 4 \cdot 8^{\mathrm{b}}(n=4)$ & $102 \cdot 1 \pm 3 \cdot 3(n=4)$ \\
\hline $92 \cdot 5 \pm 2 \cdot 7^{\mathrm{c}}(n=4)$ & $105 \cdot 5 \pm 4 \cdot 7(n=4)$ \\
\hline
\end{tabular}



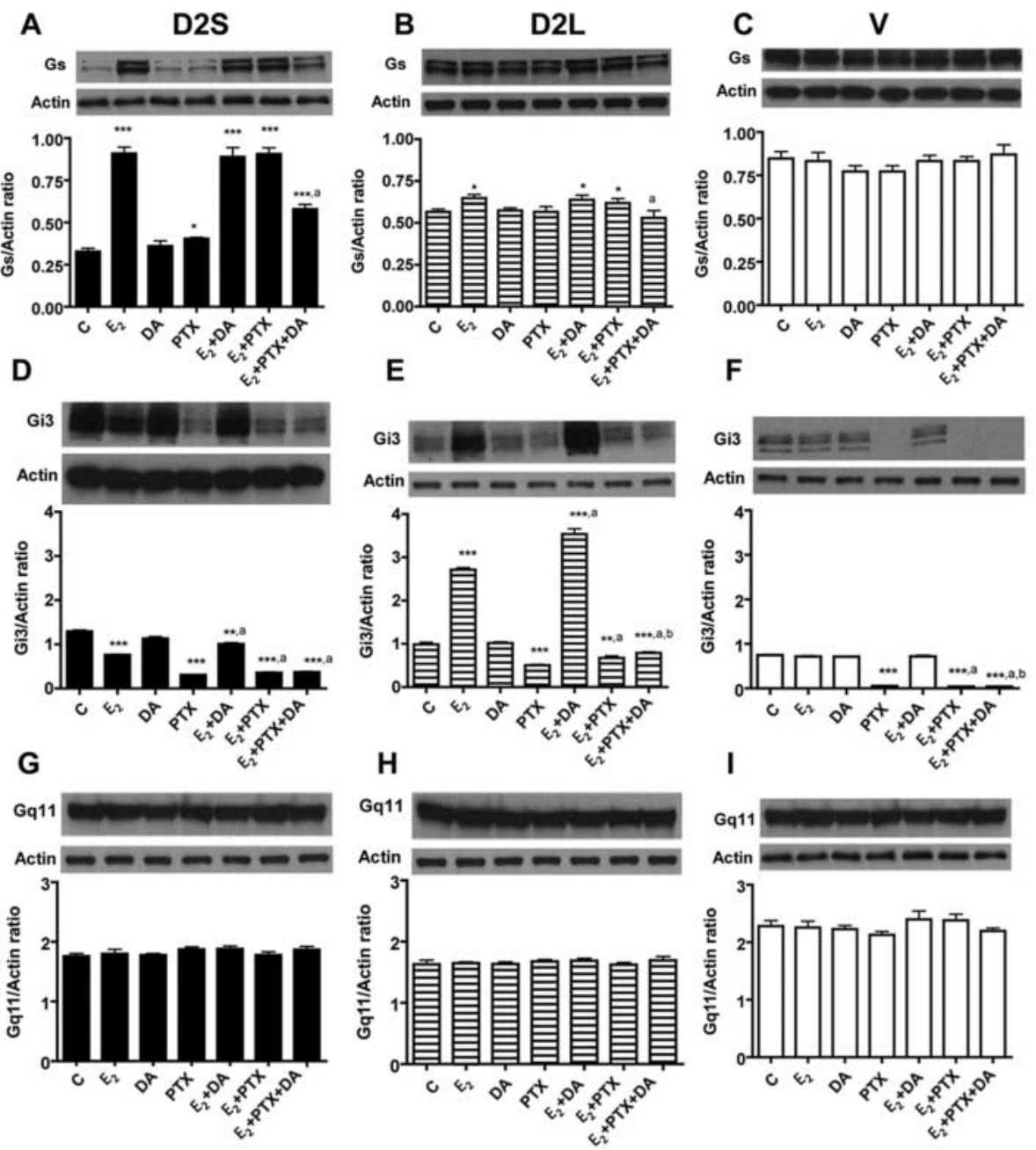

Figure 3 Effects of DA and PTX on $E_{2}$-modulated cellular levels of $G$ proteins in D2S (A, D, and G), $\mathrm{D} 2 \mathrm{~L}(\mathrm{~B}, \mathrm{E}$, and $\mathrm{H})$, and $\mathrm{V}(\mathrm{C}, \mathrm{F}$, and $\mathrm{I})$ cells. Estradiol $\left(\mathrm{E}_{2} ; 10 \mathrm{nM}\right)$ effects on cellular levels of $\mathrm{G}$ proteins were determined in D2S, D2L, and V cells in the presence or absence of DA $(10 \mu \mathrm{M})$ and PTX $(10 \mu \mathrm{g} / \mathrm{ml})$ alone or together for a period of $24 \mathrm{~h}$. Quantitation of $\mathrm{G}$ protein levels was done using western blot, and actin was used as control housekeeping protein. In each column of the figure, representative blots were shown on the top, and mean \pm S.E.M. values of $G$ protein and actin ratios were presented as histograms on the bottom. $n=4 .{ }^{*} P<0 \cdot 05,{ }^{* *} P<0 \cdot 01,{ }^{* * *} P<0 \cdot 001$, significantly different from the vehicle $(\mathrm{C})$-treated group. ${ }^{\mathrm{a}} P<0 \cdot 001$, significantly different from the $\mathrm{E}_{2}$-treated group. ${ }^{b} P<0 \cdot 001$, significantly different from the $E_{2}+$ DA-treated group.

lactotropic cells can be regulated by D2 receptor isoforms even in the absence of a D2 receptor ligand. Furthermore, the data suggest the possibility that the constitutive expression of D2S receptors might inhibit Gs while stimulating Gi3 production.

The effects of $E_{2}$ treatment on cellular levels of $G$ protein in E-LT, V, D2L, and D2S cells were compared. Using the dose $(10 \mathrm{nM})$ of $E_{2}$ that maximally increases the cellular levels of PRL and cell proliferation, we determined the steroid effect on cellular levels of Gs, Gi3, and Gq11 in these cells. As shown in Table $3, \mathrm{E}_{2}$ treatment markedly decreased Gi3 levels in E-LT and D2S cells but markedly increased Gi3 levels in D2L cells and produced no effect on Gi3 levels in $\mathrm{V}$ cells. On the other hand, $\mathrm{E}_{2}$ treatment markedly increased the level of Gs in D2S and E-LT cells and moderately increased in D2L cells but produced no effect in V cells. $E_{2}$ failed to change Gq11 levels in any of these cells. These data also identified the preference of D2S over D2L in mediating $\mathrm{E}_{2}$ stimulatory action on the cellular level of Gs protein. Additionally, these data revealed a differential action of $E_{2}$ on the cellular level of Gi3 protein under the influence of D2S and D2L receptors. 

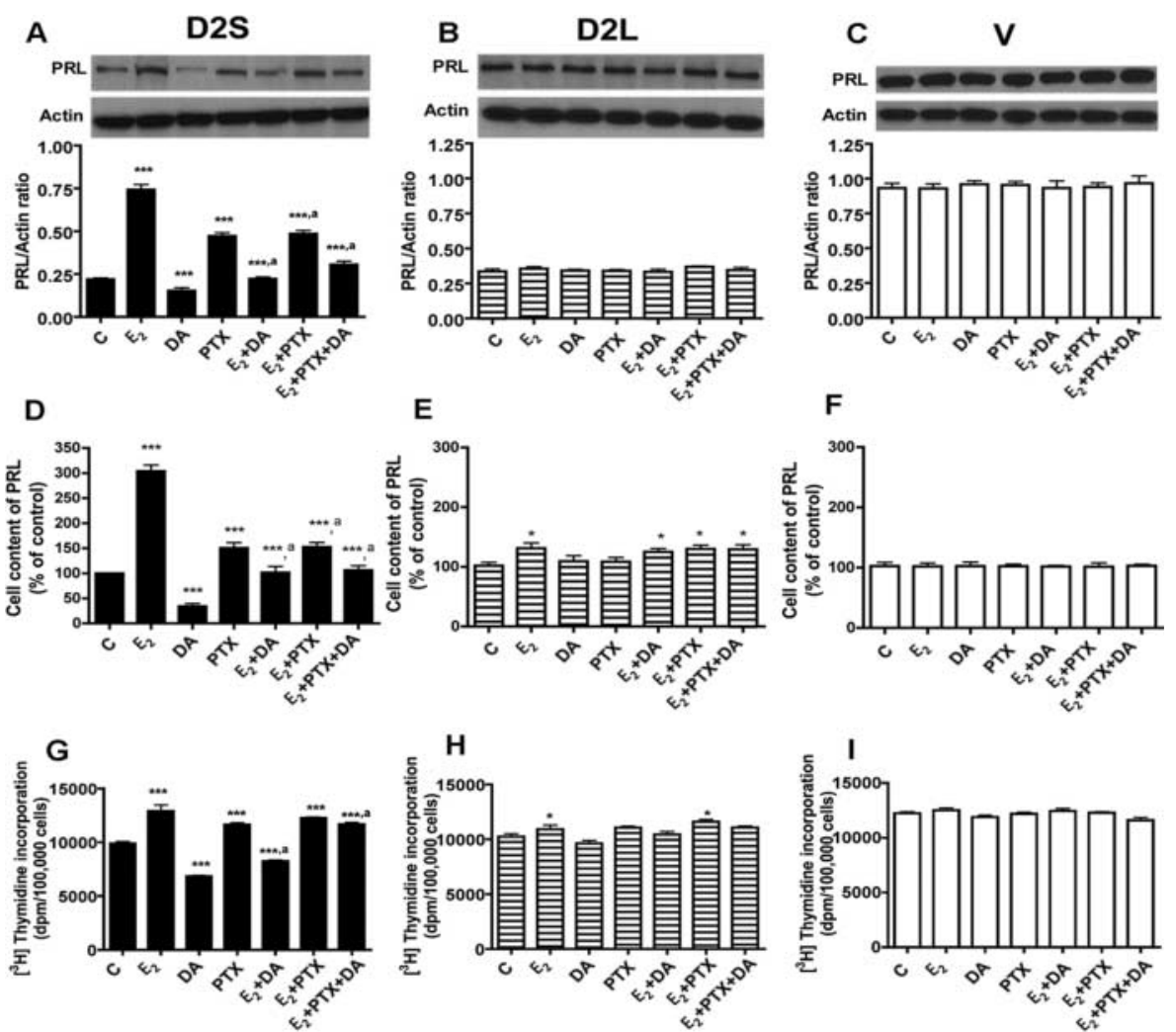

Figure 4 Effects of DA and PTX on $E_{2}$-modulated cellular PRL (A, B, C, D, E and F) and cell proliferation $(\mathrm{G}, \mathrm{H}$ and $\mathrm{I})$ in $\mathrm{D} 2 \mathrm{~S}, \mathrm{D} 2 \mathrm{~L}$, and $\mathrm{V}$ cells expressing differential amounts of $\mathrm{G}$ proteins. Cells were treated with DA or PTX as described in the legend of Fig. 3. Changes in the cellular levels of PRL were determined by western blots (A, B, and C) or ELISA (D, E, and F). In each column of the figure, representative blots are shown on the top, and mean \pm s.E.M. values of $P R L$ and actin ratios are presented as histograms on the bottom. $n=4$. $(\mathrm{G}, \mathrm{H}$ and $\mathrm{I})$. Changes in cell proliferation rate were determined by measuring the $\left[{ }^{3} \mathrm{H}\right]$-thymidine incorporation into cells.

$n=7-9 . * P<0 \cdot 05, * * P<0 \cdot 01, * * * P<0 \cdot 001$ compared with the vehicle-treated group (C).

${ }^{a} P<0 \cdot 05$, significantly different from $E_{2}$ only treatment.

Effects of DA and PTX on $E_{2}$-modulated levels of $G$ proteins in lactotropic cells expressing various levels of D2 receptor isoforms

$\mathrm{E}_{2}$ is known to prevent the ligand binding ability of D2 receptors as well as to increase the level of D2L but decrease the level of D2S receptors on lactotropes (Oomizu et al. 2003). Hence, the question arose whether the magnitude or the direction of the $\mathrm{E}_{2}$ effect on D2 ligand-modulated $\mathrm{G}$ proteins depends on the influence of D2S and/or D2L receptors. The effects of $E_{2}$ treatment in the presence of DA or in the presence of a $\mathrm{D} 2$ receptor and Gi3 coupling blocker PTX (this agent catalyses the ADP ribosylation of specific classes of $\mathrm{G}$ proteins, $\mathrm{Gi}$ and Go, thereby preventing their activation by agonist; Bokoch et al. (1983)) on cellular levels of $G$ proteins were also compared.

As shown in Fig. 3A, in D2S cells, treatment of DA produced no effect on the basal or the $\mathrm{E}_{2}$-induced level of Gs protein, while PTX moderately increased basal Gs levels.
In D2L cells, treatment of PTX, or DA, produced no effect on the basal or the $\mathrm{E}_{2}$-induced level of Gs protein, although combined treatment with PTX and DA moderately reduced the $\mathrm{E}_{2}$-induced level of Gs protein (Fig. 3B). Both DA and PTX did not alter the level of Gs protein in V cells (Fig. 3C). The DA effect on Gi3 also varies between these cells. DA inhibited $E_{2}$-altered levels of Gi3 protein in D2S cells but produced stimulation in D2L cells or no effect on levels of this protein in V cells (Fig. 3D, E and F). PTX inhibited the basal Gi3 level in all cell types and potentiated $\mathrm{E}_{2}$ 's inhibitory action on this protein level in D2S cells. Both DA and PTX failed to alter the basal or $\mathrm{E}_{2}$-induced level of $\mathrm{Gq} 11$ protein in all the cells used (Fig. 3G, H and I). These data provide additional support to the view that DA acts on D2 receptorcoupled PTX-sensitive Gi3 proteins (Civelli et al. 1993, Albert 2002) and identifies a D2S-specific role in mediation of DA's action on Gi3 protein. 
Effects of DA and PTX on $E_{2}$-modulated cellular PRL and cell proliferation in lactotropic cells expressing various levels of D2 receptor isoforms

The effects of $\mathrm{E}_{2}$ with or without DA and PTX on PRL production and cell proliferation were determined in D2S, D2L, and V cells. Changes in PRL productions in these cells were determined using both western blot and ELISA methods. As cellular levels of PRL varied between experiments, the levels of PRL were normalized as a ratio of actin in the case of western blot data or presented as percent of control in the case of ELISA data.

Similar to lactotropes (Baertschi et al. 1992, Sarkar et al. and PTX suppressed $\mathrm{E}_{2}$-induced PRL production. In D2L cells, DA or PTX produced no significant effect on either basal or $\mathrm{E}_{2}$-induced changes in cellular levels of PRL (Fig. 4B and $\mathrm{E})$. In $\mathrm{V}$ cells, neither $\mathrm{E}_{2}$ nor the DA altered cellular levels of PRL (Fig. 4C and F).

Like PRL production in D2S cells, DA decreased and PTX increased the basal level of thymidine incorporation into cells (Fig. 4D). Both DA and PTX inhibited the $\mathrm{E}_{2}$-induced thymidine incorporation into D2S cells. In D2L cells, both DA and PTX produce very moderate or no effect on basal and $\mathrm{E}_{2}$-induced thymidine incorporation into cells (Fig. 4E). In $\mathrm{V}$ cells, the DA or PTX failed to alter thymidine incorporation receptors, at least partly, mediate the $\mathrm{E}_{2}$ actions on $\mathrm{PRL}$ production and cell proliferation in lactotropes. Additionally, the data support a preferential role of D2S in regulation of $\mathrm{E}_{2^{-}}$ induced PRL production and cell proliferation in lactotropes.

Effects of Gi3 blocking by siRNA on PRL levels in lactotropic cells expressing various levels of $\mathrm{D} 2$ receptor isoforms

To further determine the role of D2 receptor isoforms and Gi3 and Gs proteins in $\mathrm{E}_{2}$ action on PRL production, we also employed an siRNA approach to knockdown the Gs or Gi3 genes and proteins in D2S and D2L cells. Transfection of Gs siRNA markedly reduced the cellular level of this protein in D2S (Fig. 5A) and D2L cells (Fig. 5B) without affecting Gi3 protein levels in these cells (Fig. 5C and D). Gs blockade significantly reduced $\mathrm{E}_{2}$ effect on PRL in D2S cells (Fig. $5 \mathrm{E}$ this $G$ protein is involved in mediation of $E_{2}$ stimulatory action on PRL.

Transfection of Gi3 siRNA markedly reduced the cellular level of this protein in D2S (Fig. 6A) and D2L cells (Fig. 6B). Interestingly, Gi3 suppression elevated Gs levels only in D2S cells (Fig. 6C) and not in D2L cells (Fig. 6D), suggesting a possible existence of an inhibitory control of Gi3 over Gs production in the D2S cell. Under Gi3 blockade, both the basal PRL level and $E_{2}$-induced PRL production were significantly increased in D2S cells (Fig. 6E and G), suggesting that the Gi3 blockade increases PRL level. Gi3 blockade did 2005), in D2S cells, DA decreased and PTX increased the basal level of cellular PRL (Fig. 4A and D). In D2S cells, DA into cells (Fig. 4F). These data identify that DA and D2 and $\mathrm{G}$ ) but not in D2L cells (Fig. 5F and H), suggesting that

not alter basal or $\mathrm{E}_{2}$-stimulated PRL production in $\mathrm{D} 2 \mathrm{~L}$ cells (Fig. 6F and $\mathrm{H}$ ). These results suggest that there exists an inhibitory interaction between Gi3 on Gs that controls D2Smediated actions on lactotropes. Furthermore, the results support the concept that $\mathrm{E}_{2}$, by suppressing Gi3, enhances Gs-regulated PRL production in lactotropes.

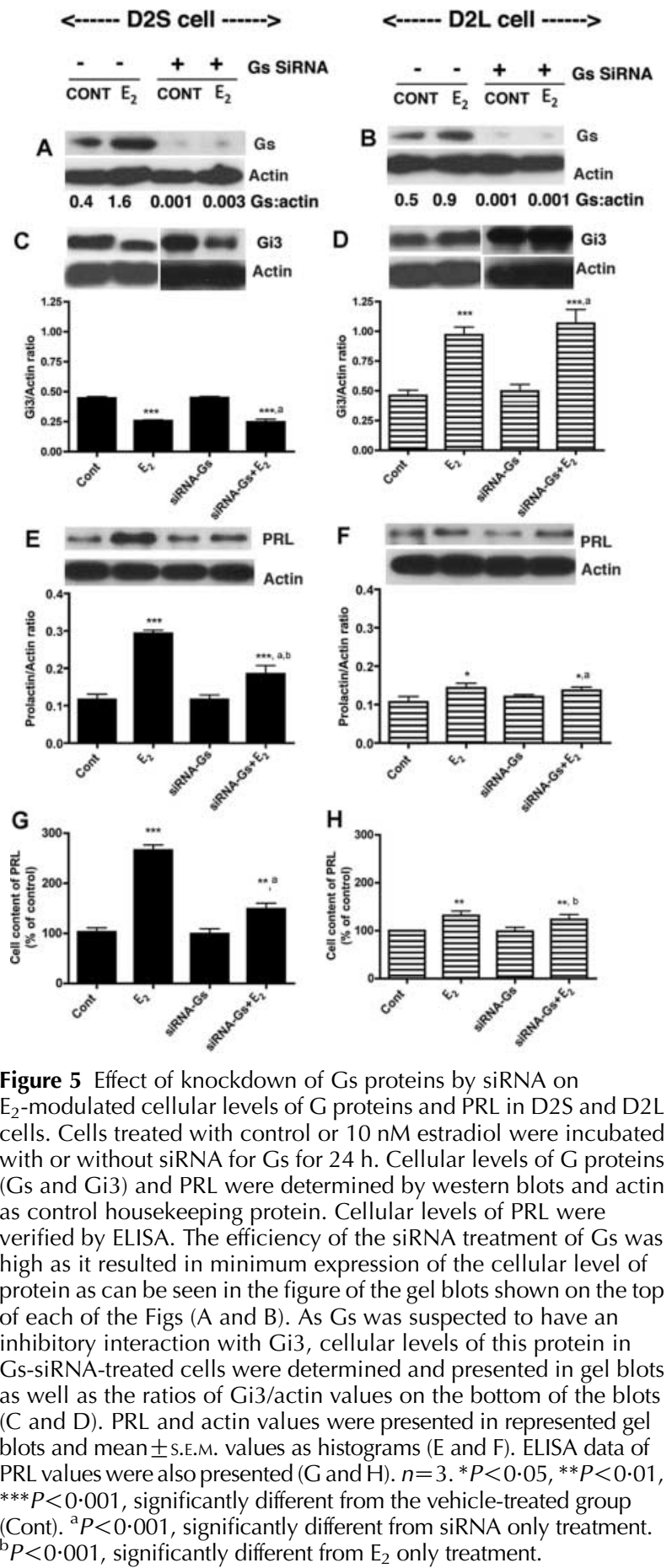




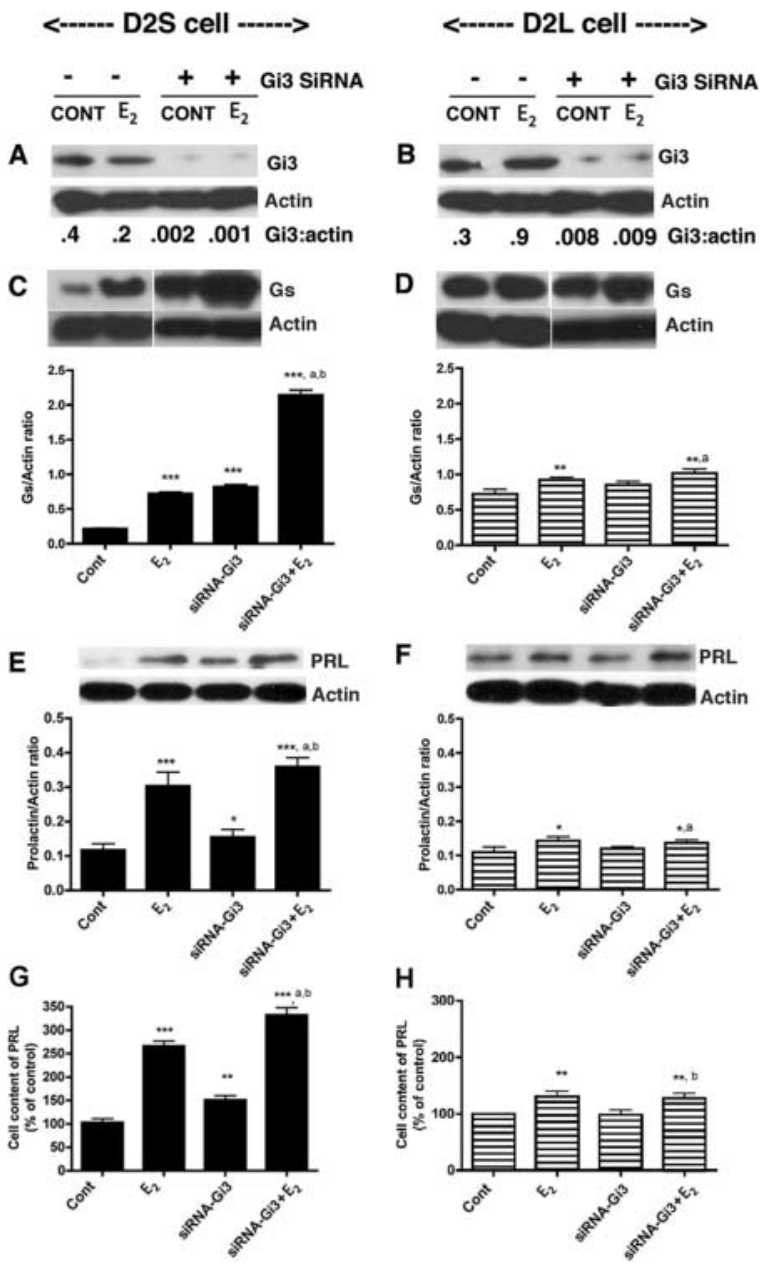

Figure 6 Effect of knockdown of Gi3 proteins by siRNA on $\mathrm{E}_{2}$-modulated cellular levels of $\mathrm{G}$ proteins and PRL in D2S and D2L cells. Cells treated with control or $10 \mathrm{nM}$ estradiol were incubated with or without siRNA for $\mathrm{Gi} 3$ for $24 \mathrm{~h}$. Cellular levels of $\mathrm{G}$ proteins (Gi3 and Gs) and PRL were determined by western blots and actin as control housekeeping protein. Cellular levels of PRL were verified by ELISA. The efficiency of the siRNA treatment of Gi3 was high as it resulted in minimum expression of the cellular level of protein as can be seen in the figure of the gel blots shown on the top of each of the Figs (A and B). As Gi3 was suspected to have an inhibitory interaction with Gs, cellular levels of Gs protein in Gi3siRNA-treated cells were determined and presented in gel blots as well as the ratios of Gs/actin values on the bottom of the blots (C and D). PRL and actin values were presented in represented gel blots and mean \pm S.E.M. values as histograms ( $E$ and F). ELISA data of PRL values were also presented ( $\mathrm{G}$ and $\mathrm{H}) . n=3 .{ }^{*} P<0 \cdot 05,{ }^{* *} P<0 \cdot 01$, $* * * P<0 \cdot 001$, significantly different from the vehicle-treated group (Cont). ${ }^{\mathrm{a}} P<0 \cdot 001$, significantly different from siRNA only treatment. ${ }^{\mathrm{b}} \mathrm{P}<0 \cdot 001$, significantly different from $\mathrm{E}_{2}$ only treatment.

\section{Discussion}

The data presented here show that D2 receptor knockdown increases the basal while reduces $\mathrm{E}_{2}$-induced PRL production and cell proliferation in lactotropes. Selective expression of recombinant D2S reduces basal PRL production and cell proliferation and reinitiates $\mathrm{E}_{2}$ actions on these two cell functions of lactotropes. Selective expression of D2L very moderately affects $\mathrm{E}_{2}$-induced lactotropic cell function. These data also identify a differential regulation of Gi3 and Gs expression by D2S and D2L receptors. Furthermore, these data provide evidence that there exists a negative interaction between Gi3 and Gs proteins that is regulated by D2S. $\mathrm{E}_{2}$, by reducing D2S expression, releases the Gi3 inhibition over Gs, causing elevation of PRL synthesis and cell proliferation in lactotropes.

$\mathrm{E}_{2}$ is known to be a physiological regulator of lactotropes in the pituitary gland. The steroid-controlled PRL secretion, $P R L$ gene transcription, and lactotropic cell proliferation, and excess $E_{2}$ stimulation increases the incidence of lactotropic tumors (prolactinomas) in the pituitary (Vallar \& Meldolesi 1989). Although $E_{2}$ 's direct action on PRL promoter site and on various growth regulatory factors has been identified, the steroid is known to suppress the inhibitory response of lactotropes to DArgic agents (Vallar \& Meldolesi 1989). Additionally, reduction of D2 receptors and knocking down the D2 receptor lead to a high PRL production and the development of prolactinomas (Cristina et al. 2006, Hnasko et al. 2007). $\mathrm{E}_{2}$ is known to affect $\mathrm{D} 2$ receptor splicing and increases the ratio of D2L and D2S receptor numbers or mRNA levels in lactotropes (Guivarc'h et al. 1998, Oomizu et al. 2003). This differential splicing of $\mathrm{D} 2$ receptor isoforms might be a critical mechanism of $\mathrm{E}_{2}$ action on lactotropes, as a negative correlation between D2S and ER $\alpha$ mRNA expression and a positive correlation between D2L and $\mathrm{ER} \propto \mathrm{mRNA}$ expression were found in human prolactinomas (Wu et al. 2009). The data obtained from this study also indicated that $\mathrm{E}_{2}$ was able to markedly increase PRL production and cell proliferation in cells expressing D2S receptor but produced a very moderate effect in cells producing D2L receptors. The proportion of mRNA corresponding to the $\mathrm{D} 2 \mathrm{~S}$ but not the $\mathrm{D} 2 \mathrm{~L}$ was shown to be low in DA-resistant compared with DA-responsive prolactinomas (Caccavelli et al. 1994). Additionally, using D2L $\mathrm{L}^{-1-}$ mice, it was shown that the function of D2S is not dependent on the formation of a receptor heterodimer with D2L (Xu et al. 2002). It has recently been shown that transgenic mice, overexpressing D2S but not D2L, show pituitary hypoplasia (Laccarino et al. 2002). Together, these data suggest that the suppression of D2S receptor expression may be a critical step in $\mathrm{E}_{2}$-regulated PRL production and lactotropic cell proliferation.

The data presented here showed that differential expression of D2 receptor in the absence of ligands could significantly affect PRL production and cell proliferation in lactotropic cells. This is evident in the experiment where cell functions were evaluated in clonal cells expressing various levels of D2 receptor isoforms. It was found that $\mathrm{V}$ cells, which lacked functional D2 receptors and had higher basal levels of PRL and thymidine uptake, showed a ligand-independent reduction in PRL production and cell proliferation rate 
following D2S and D2L receptor transfection. As described by an extended allosteric ternary complex model of $G$ protein-coupled receptor activation, receptors spontaneously isomerize between active and inactive conformations, so receptors can modulate signaling pathways in the absence of an agonist (Strange 1999). In addition, significant constitutive activity of recombinant $\mathrm{D} 2 \mathrm{~S}$ receptors expressed in mammalian cells has been described previously (Wiens et al. 1998). Hence, the ligand-independent changes in hormone production and cell proliferation were due to constitutively activated $\mathrm{D} 2$ receptors in transfected cells. $\mathrm{V}$ cells that lacked functional D2 receptors did not respond to $E_{2}$. However, $E_{2}$ stimulated PRL production and cell proliferation in the absence as well as in the presence of D2 receptor ligands in these cells following D2 receptor transfection. $\mathrm{E}_{2}$ is known to alter the expression of D2 receptors (Oomizu et al. 2003). Hence, $E_{2}$ effects on PRL production and cell proliferation in D2S cells without DA are possibly a result of the steroid suppression of D2 receptor expression rather than prevention of the ligand activation of $\mathrm{D} 2$ receptors.

Although the physiological dose range of DA inhibits PRL release, lower doses of DA increases PRL (Freeman et al. 2000, Ben-Jonathan \& Hnasko 2001). The differential dosedependent effects of DA on PRL secretion involve different G proteins (Burris \& Freeman 1993), though this could not be confirmed as involving different isoforms of the D2 receptor (Burris \& Freeman 1994). We did not find a strong effect of DA on PRL production in D2L cells. Hence, it is possible that the major effect of $\mathrm{D} 2 \mathrm{~L}$ might be related to $\mathrm{D} 2$ receptor-mediated PRL secretion and this receptor isoform might minimally regulate D2 receptor-mediated PRL production. The inhibitory action of DA on lactotropes involves alteration of $G$ protein coupling that results in inhibition of adenylyl cyclase and reduction of intercellular cAMP and PRL production and possibly cell proliferation (Enjalbert \& Bockaert 1983, Martinez de la Escalera et al. 1988). The D2S receptor is known to couple to Gi2 to inhibit forskolin-induced cAMP production, while it coupled to Gi3 to inhibit adenylate cyclase activated by a Gs-coupled receptor (PGE1 receptor). D2S-induced increase in $\left[\mathrm{Ca}^{2++}\right]$ is not dependent on any particular Gi/o subtype but is dependent on mobilization of $G \beta \gamma$ subunit (Ghahremani et al. 1999). Therefore, the DA D2S receptor uses different Gi/o protein subunits to regulate a diversity of effectors' functions within the cell. In this study, we identified $\mathrm{E}_{2}$ stimulatory action on Gs and inhibitory action on Gi3 in D2S cells but not clearly in D2L cells; in these cells, $\mathrm{E}_{2}$ moderately stimulated both Gi3 and Gs. In D2S cells, $\mathrm{E}_{2}$ actions on Gi3 and PRL production and on cell proliferation were suppressed by DA as well as by PTX. $\mathrm{E}_{2}$ increased Gs levels in D2S cells that were not inhibited by DA or PTX. Similarly, $E_{2}$ stimulatory action on Gs in D2L cells is minimally affected by DA or PTX. Previous studies identified that D2 receptors are positively coupled with PTX-sensitive Gi3 proteins, which reduce the cellular level of cAMP and thereby $P R L$ gene production and cell proliferation in lactotropes
(Ghahremani et al. 1999). We here showed that a Gi3 blocker was able to stimulate the basal level of PRL while a Gs blocker was able to inhibit $\mathrm{E}_{2}$ action on PRL production in D2S cells but not in D2L cells. It is noteworthy that Gi3 suppression by siRNA increased the cellular levels of Gs in D2S cells. In D2S cells, $\mathrm{E}_{2}$ suppressed Gi3 and increased Gs, thus showing a reversal expression of these two proteins under the influence of the steroid. On the other hand, in D2L cells, $E_{2}$ moderately increased both Gs and Gi3, showing a moderate and nonreversal effect on these two $G$ proteins. These data support the concept that Gs proteins are under inhibitory control by Gi3 in lactotropes. Furthermore, the data identify the critical importance of removal of the inhibitory action of Gi3 on Gs in the regulation of $\mathrm{E}_{2}$ action on lactotropic cells.

Hence, it appears that $\mathrm{E}_{2}$ suppresses the D2S-regulated coupling of PTX-sensitive Gi3 protein and activates Gs protein-mediated signaling to stimulate PRL production and cell proliferation in lactotropes. Furthermore, by increasing the production of $\mathrm{D} 2 \mathrm{~L}, \mathrm{E}_{2}$ may decouple the $\mathrm{D} 2$ receptor influence on Gi3 and Gs interaction and thereby reduce the dopaminergic inhibitory control over PRL production and cell proliferation.

\section{Declaration of interest}

The authors declare that there is no conflict of interest that could be perceived as prejudicing the impartiality of the research reported.

\section{Funding}

This work was supported by National Institutes of Health grant AA 11591.

\section{Author contribution statement}

This study was designed by D K S and experiments were performed by A S. All the authors jointly analyzed and interpreted the data and D K S wrote the paper.

\section{Acknowledgements}

The authors would like to thank E Michael Clement, D Kethidi, M E Wozniak, and P Deep for technical help and NIDDK for providing PRL antibody for western blots.

\section{References}

Albert PR 2002 G protein preferences for dopamine D2 inhibition of prolactin secretion and DNA synthesis in GH4 pituitary cells. Molecular Endocrinology 16 1903-1911. (doi:10.1210/me.2001-0329)

Baertschi AJ, Audigier Y, Lledo PM, Israel JM, Bockaert J \& Vincent JD 1992 Dialysis of lactotropes with antisense oligonucleotides assigns guanine nucleotide binding protein subtypes to their channel effectors. Molecular Endocrinology 6 2257-2265. (doi:10.1210/me.6.12.2257) 
Baldwin JM 1994 Structure and function of receptors coupled to $G$ proteins. Current Opinion in Cell Biology 6 180-190. (doi:10.1016/0955-0674 (94)90134-1)

Ben-Jonathan N \& Hnasko R 2001 Dopamine as a prolactin (PRL) inhibitor. Endocrine Reviews 22 724-763. (doi:10.1210/er.22.6.724)

Bokoch GM, Katada T, Northup JK, Hewlett EL \& Gilman AG 1983 Identification of the predominant substrate for ADP-ribosylation by islet activating protein. Journal of Biological Chemistry $\mathbf{2 5 8}$ 2072-2075.

Bosse R, Fumagalli F, Jaber M, Giros B, Gainetdinov RR, Wetsel WC, Missale C \& Caron MG 1997 Anterior pituitary hypoplasia and dwarfism in mice lacking the dopamine transporter. Neuron 19127-19138.

Burris TP \& Freeman ME 1993 Low concentrations of dopamine increase cytosolic calcium in lactotrophs. Endocrinology 133 63-68. (doi:10.1210/en. 133.1.63)

Burris TP \& Freeman ME 1994 Comparison of the forms of the dopamine D2 receptor expressed in GH4C1 cells. Proceedings of the Society for Experimental Biology and Medicine 205 226-335.

Caccavelli L, Feron F, Morange I, Rouer E, Benarous R, Dewailly D, Jaquet P, Kordon C \& Enjalbert A 1994 Decreased expression of the two D2 dopamine receptor isoforms in bromocriptine-resistant prolactinomas. Neuroendocrinology 60 314-322. (doi:10.1159/000126764)

Caporali S, Imai M, Altucci L, Cancemi M, Caristi S, Cicatiello L, Matarese F, Penta R, Sarkar DK, Bresciani F et al. 2003 Distinct signaling pathways mediate stimulation of cell cycle progression and prevention of apoptotic cell death by estrogen in rat pituitary tumor PR1 cells. Molecular Biology of the Cell 14 5051-5059. (doi:10.1091/mbc.E0305-0303)

Chaturvedi K \& Sarkar DK 2008 Alteration in G proteins and prolactin levels in pituitary after ethanol and estrogen treatment. Alcoholism, Clinical and Experimental Research 32 806-813. (doi:10.1111/j.1530-0277.2008. 00638.x)

Chun T-Y, Gregg D, Sarkar DK \& Gorski J 1998 Differential regulation by estrogens of growth and prolactin synthesis in pituitary cells suggests that only a small pool of estrogen receptors is required for growth. PNAS $\mathbf{9 5}$ 2325-2330. (doi:10.1073/pnas.95.5.2325)

Civelli O, Bunzow JR \& Grandy DK 1993 Molecular diversity of the dopamine receptors. Annual Review of Pharmacology and Toxicology 33 281-307. (doi:10.1146/annurev.pa.33.040193.001433)

Cristina C, García-Tornadú I, Díaz-Torga G, Rubinstein M, Low MJ, Becú-Villalobos D, García-Tornadú I, Díaz-Torga G, Rubinstein M, Low MJ \& Becú-Villalobos D 2006 Dopaminergic D2 receptor knockout mouse: an animal model of prolactinoma. Frontiers of Hormone Research 35 50-63. (doi:full_text)

Enjalbert A \& Bockaert J 1983 Pharmacological characterization of the D2 dopamine receptor negatively coupled with adenylate cyclase in rat anterior pituitary. Molecular Pharmacology 23 576-584.

Freeman ME, Kanyicska B, Lerant A \& Nagy G 2000 Prolactin: structure, function, and regulation of secretion. Physiological Reviews $\mathbf{8 0}$ 1523-1631.

Gershengorn MC \& Osman R 1996 Molecular and cellular biology of thyrotropin-releasing hormone receptors. Physiological Reviews $\mathbf{7 6}$ 175-191.

Ghahremani MH, Cheng P, Lembo PMC \& Albert PR 1999 Distinct roles for Gai2, Gai3, and Gbg in modulation of forskolin- or Gs-mediated cAMP accumulation and calcium mobilization by dopamine D2S receptors. Journal of Biological Chemistry 274 9238-9245. (doi:10.1074/jbc.274.14. 9238)

Guiramand J, Montmayeur JP, Ceraline J, Bhatia M \& Borrelli E 1995 Alternative splicing of the dopamine D2 receptor directs specificity of coupling to G-proteins. Journal of Biological Chemistry 270 7354-7358. (doi:10.1074/jbc.270.13.7354)

Guivarc'h D, Vincent JD \& Vernier P 1998 Alternative splicing of the D2 dopamine receptor messenger ribonucleic acid is modulated by activated sex steroid receptors in the MMQ prolactin cell line. Endocrinology 139 4213-4221. (doi:10.1210/en.139.10.4213)
Hentges S, Boyadjieva N \& Sarkar DK 2000 Transforming growth factor- $\beta 3$ stimulates lactotrope cell growth by increasing basic fibroblast growth factor from folliculo-stellate cells. Endocrinology 141 859-867. (doi:10.1210/en. 141.3.859)

Hnasko TS, Hnasko RM, Sotak BN, Kapur RP \& Palmiter RD 2007 Genetic disruption of dopamine production results in pituitary adenomas and severe prolactinemia. Neuroendocrinology 86 48-57. (doi:10.1159/000105242)

Kelly MA, Rubinstein M, Asa SL, Zhang G, Saez C, Bunzow JR, Allen RG, Hnasko R, Ben-Jonathan N, Grandy DK et al. 1997 Pituitary lactotroph hyperplasia and chronic hyperprolactinemia in dopamine D2 receptor-deficient mice. Neuron 19 103-113. (doi:10.1016/S08966273(00)80351-7)

Kineman RD, Gettys TW \& Frawley LS 1996 Role of guanine nucleotidebinding proteins, Gi alpha 3 and Gs alpha, in dopamine and thyrotropinreleasing hormone signal transduction: evidence for competition and commonality. Journal of Endocrinology 148 447-455. (doi:10.1677/joe.0. 1480447)

Laccarino C, Samad TK, Mathis C, Kercret H, Picetti R \& Borrelli E 2002 Control of lactotroph proliferation by dopamine: essential role of signalling through D2 receptors ERKs. PNAS 99 14530-14535. (doi:10.1073/pnas. 222319599)

Livingstone JD, Lerant A \& Freeman ME 1998 Ovarian steroids modulate responsiveness to dopamine and expression of G-proteins in lactotropes. Neuroendocrinology 68 172-179. (doi:10.1159/000054363)

Martinez de la Escalera G, Guthrie J \& Weiner RI 1988 Transient removal of dopamine potentiates the stimulation of prolactin release by TRH but not VIP: stimulation via $\mathrm{Ca}^{2+}$ /protein kinase C pathway. Neuroendocrinology 47 38-45. (doi:10.1159/000124888)

Maurer RA 1989 Both isoforms of the cAMP-dependent protein kinase catalytic subunit can activate transcription of the prolactin gene. Journal of Biological Chemistry 264 6870-6873.

Oomizu S, Boyadjieva N \& Sarkar DK 2003 Ethanol and estradiol modulate alternative splicing of dopamine D2 receptor mRNA and abolish the inhibitory action of bromocriptine on prolactin release from the pituitary gland. Alcoholism, Clinical and Experimental Research 27 975-980. (doi:10.1111/j.1530-0277.2003.tb04423.x)

Pastorcic M, De A, Boyadjieva N, Vale W \& Sarkar DK 1995 Reduction in the expression and action of transforming growth factor beta 1 on lactotropes during estrogen-induced tumorigenesis in the anterior pituitary. Cancer Research 55 4892-4898.

Saiardi A, Bozzi Y, Baik JH \& Borrelli E 1997 Antiproliferative role of dopamine: loss of D2 receptors causes hormonal dysfunction and pituitary hyperplasia. Neuron 19 115-126. (doi:10.1016/S0896$6273(00) 80352-9)$

Sarkar DK 2006 Genesis of prolactinomas: studies using estrogen-treated animals. Frontiers of Hormone Research 35 32-49.

Sarkar DK, Gottschall PE \& Meites J 1982 Damage to hypothalamic dopaminergic neurons is associated with development of prolactinsecreting pituitary tumors. Science 218 684-686. (doi:10.1126/science. 7134966)

Sarkar DK, Chaturvedi K, Oomizu S, Boyadjieva NI \& Chen CP 2005 Dopamine, dopamine D2 receptor short isoform, transforming growth factor (TGF)-beta1, and TGF-beta type II receptor interact to inhibit the growth of pituitary lactotropes. Endocrinology 146 4179-4188. (doi:10. 1210/en.2005-0430)

Strange PG 1999 Agonism and inverse agonism at dopamine D2-like receptor. Clinical and Experimental Pharmacology \& Physiology. Supplement 26 53-59.

Radl DB, Ferraris J, Boti V, Seilicovich A, Sarkar DK \& Pisera D 2011 Dopamine-induced apoptosis of lactotropes is mediated by the short isoform of D2 receptor. PLoS ONE 6 e18097. (doi:10.1371/journal.pone. 0018097)

Usiello A, Baik JH, Rougé-Pont F, Picetti R, Dierich A, LeMeur M, Piazza PV \& Borrelli E 2000 Distinct functions of the two isoforms of dopamine D2 receptors. Nature 408 199-203. (doi:10.1038/35041572)

Vallar L \& Meldolesi J 1989 Mechanisms of signal transduction at the dopamine D2 receptor. Trends in Pharmacological Sciences 10 74-77. (doi:10.1016/0165-6147(89)90082-5) 
Wang Y, Xu R, Sasaoka T, Tonegawa S, Kung MP \& Sankoorikal EB 2000 Dopamine D2 long receptor-deficient mice display alterations in striatum-dependent functions. Journal of Neuroscience 20 8305-8314.

Wiens BL, Nelson CS \& Neve KA 1998 Contribution of serine residues to constitutive and agonist-induced signaling via the D2S dopamine receptor: evidence for multiple, agonist-specific active conformations. Molecular Pharmacology 54 435-444.

Wu ZB, Li CZ, Zong XY, Su ZP, Zeng YJ \& Zhang YZ 2009 Correlation of alternative splicing of the D2 dopamine receptor mRNA and estrogen receptor mRNA in the prolactinomas and gonadotrope tumors. Journal of Neuro-Oncology 94 135-139. (doi:10.1007/s11060-009-9816-5)
Xu R, Parlow AF \& Wang Y 2002 The effects of dopamine and D2 receptor antagonists on pituitary hormone secretion are intact in mice lacking dopamine D2L receptor. Brain Research 939 95-99. (doi:10.1016/S00068993(02)02559-3)

Received in final form 23 March 2012

Accepted 9 May 2012

Made available online as an Accepted Preprint 9 May 2012 